Article

\title{
Ti-SLActive and TiZr-SLActive Dental Implant Surfaces Promote Fast Osteoblast Differentiation
}

\author{
Milena R. Kaluđerović ${ }^{1, *}$, Tamara Krajnović ${ }^{2}$, Danijela Maksimović-Ivanić ${ }^{2}$, \\ Hans-Ludwig Graf ${ }^{1}$ and Sanja Mijatović ${ }^{2}$ \\ 1 Department of Oral, Maxillary, Facial and Reconstructive Plastic Surgery, University Hospital of Leipzig, \\ 04103 Leipzig, Germany; hans-ludwig.graf@medizin.uni-leipzig.de \\ 2 Department of Immunology, Institute for Biological Research “Sinisa Stankovic”, University of Belgrade, \\ Bulevar despota Stefana 142, 11060 Belgrade, Serbia; tamara_krajnovic@yahoo.com (T.K.); \\ nelamax@ibiss.bg.ac.rs (D.M.-I.); sanjamama@ibiss.bg.ac.rs (S.M.) \\ * Correspondence: milena.kaluderovic@medizin.uni-leipzig.de; Tel.: +49-341-972-1106
}

Received: 21 June 2017; Accepted: 12 July 2017; Published: 15 July 2017

\begin{abstract}
A primary goal in modern surface modification technology of dental implants is to achieve biocompatible surfaces with rapid but controlled healing which also allow health and longevity of implants. In order to realize all, understanding of osseointegration phenomena is crucial. Although Ti-SLA, Ti-SLActive and TiZr-SLActive surfaces have been successfully used in clinical implantology and were shown to notably reduce the primary healing time, available in vitro studies are sparse and do not concern or explore the mechanism(s) involved in human osteoblast behavior on these surfaces. Ti-SLA, Ti-SLActive, TiZr-SLActive, Ti cp, Ticer and Cercon surfaces were used. Osteoblast proliferation, cell cluster formation, morphological changes, induction of autophagy, nitric oxide (NO), reactive oxygen species/reactive nitrogen species (ROS/RNS) formation, osteocalcin (OC), bone sialoprotein (BSP) and collagen type I (Col-1) affected by various surfaces were analyzed. These surfaces induced formation of mature osteoblasts caused by elevated oxidative stress (ROS) followed by overexpression of osteoblast maturation key molecule (NO), with different intensity however. These mature osteoblasts induced upregulation of OC, BSP and Col-1, activating PI3/Akt signalling pathway resulting in autophagy, known as an important process in differentiation of osteoblast cells. Additional distinctive subpopulation identified on Ticer, Ti-SLA (after 5 days), Ti-SLActive and TiZr-SLActive surfaces (after 2 days) were forming cell clusters, essential for bone noduli formation and mineralisation. The results suggest that Ti- and TiZr-SLActive possess advanced properties in comparison with Ticer and Ti-SLA manifested as accelerated osteoblast differentiation. These effects could explain already known fast osseointegration of these surfaces in vivo.
\end{abstract}

Keywords: implant surfaces; osteoblast; Ticer; SLA; autophagy

\section{Introduction}

The development of novel dental implant materials as well as elucidation of cellular and acellular healing mechanisms between implant surface and surrounding solid and soft tissues have been in progress for over six decades, i.e., from Brånemark's discovery demonstrating that titanium could become permanently incorporated into bone [1,2]. In terms of biocompatibility and osseointegration, Ti cp (commercially pure titanium) represents the golden standard in implant dentistry [3]. Since it has been shown that physicochemical properties (chemical composition, surface roughness, micro/nanotopography, wettability, surface charges, etc.) have the most important influence on cell adhesion, proliferation, differentiation and bone matrix deposition [4,5], major improvements in material surface development have been achieved in order to reduce the critical confronts of the implant dentistry. Employing different techniques in preparation of implant surfaces 
(such as machining, acid etching, anodization, plasma spraying, grit blasting or combination methods) contributed to materials with improved integration processes [6-8]. Many years of research resulted in several improved materials with advanced mechanical properties, as well as enhanced biocompatibility and osseointegration $[9,10]$.

Nevertheless, as osseointegration and longevity of implants have been enhanced and prolonged, clinical indications for implantation expanded as well. Thus, implants were also introduced to patients with very challenging indications, e.g., in irradiated jaws or poor bone quality. Furthermore, since it was shown that implant size at macro level can be reduced by increasing the surface area at micro level, short implants and implants with reduced diameter have been introduced. Consequently, expectations of the patients were also increased. Obviously, not only successful functional and excellent esthetic solutions were awaited, but also short and predictable healing time enabling fast loading of implants. In accordance with the abovementioned, the use of titanium dental implants in clinical practice increased dramatically. Ticer (ZL Microdent, Breckefeld, Germany), a dental implant with an anodically oxidized surface, introduced in the 1980s [11] represents a widely used and the first among similar materials employed in clinical practice. It was found to promote fast osteoblast cell differentiation and mineralization processes [12,13]. Ti-SLA (Institut Straumann AG, Basel, Switzerland) represents the surface obtained by combining sandblasting and acid-etching of titanium implant surfaces which enhance bone integration and long-term stability [3]. Rinsing the Ti-SLA surfaces under nitrogen and storing in a saline solution yielded Ti-SLActive surface (Institut Straumann AG, Basel, Switzerland) with improved initial wetting conditions that acted lowering contaminations and its surface was more active than that of Ti-SLA, expressing beneficial effects on cell differentiation and growth factor production [3,14-16]. Introducing the Ti-SLActive surfaces in the implantology enabled reduction of primary healing time (from 6 months to 6 weeks) and more rapid loading of implants [15,17].

Furthermore, in order to solve the esthetic issues of dark-grayish color of titanium implants in some cases visible through gingiva, Cercon (yttrium tetragonal zirconia-based material; DeguDent, Rodenbacher, Hanu, Germany) have been created and used in the esthetic zone, as well as in stress bearing regions [18]. Research related to dental implant surfaces also pointed to the combination of zirconia and titanium [19,20], e.g., implant body of zirconia and a surface coating of titanium oxide or vice versa [21-24]. The first attempts did not solve difficulties related to the mechanical stability of zirconia and potential toxicity of titanium ions, while surfaces with an implant body of titanium and a surface coating of zirconia expressed beneficial in vitro effects on osteoblast cells similar to Ticer, but the color problems remained.

With the aim of improving mechanical stability of the implants, enabling usage of shorter implants and implants with reduced diameter in the atrophic bones, titanium-based alloys were introduced. Due to their exceptional mechanical strength, corrosion resistance and very satisfactory biocompatibility, their application is continually increasing [25-27]. Ti6Al4V and TiZr are the most interesting alloys [3,28]. It is well documented that implant diameter represents one of the most important parameters which exhibit great impacts on the implant fracture [29]. Titanium implants with diameters below $4 \mathrm{~mm}$ in the masticator zone demonstrate low fracture resistance and therefore they cannot be used for that purpose. Since alloys possess unique mechanical strength, they can be employed to prepare implants with reduced diameter [30,31]. The application of these implants enables to avoid complicated augmentation techniques and treatment of tight spaces upon teeth extraction. In 2009, Bernhard et al. developed binary titanium-zirconium alloy Roxolid (TiZr; ca. 15\% Zr; Institut Straumann AG, Basel, Switzerland) with SLActive surfaces which expressed improved osseointegration [32]. Introducing TiZr-alloys in implant dentistry allowed application of implants with reduced diameter (e.g., Straumann: $3.3 \mathrm{~mm}$ for incisors and premolar; $2.9 \mathrm{~mm}$ for the lower incisors and upper lateral incisors).

To the best of our knowledge, there is no dental implant material which solves either all clinical problems, or patients' satisfaction. Even though numerous preclinical and clinical investigations were performed so far, the process of osseointegration has still not been completely identified at the cellular level on the material-bone interface. Implants with rough surfaces have been recognized 
as materials that do not promote osteoblast proliferation (a sign of a more differentiated cellular phenotype in culture) [33-35], but they are able to enhance their maturation and consequently differentiation process [36-38]. Few reports indicated that this incident might be affected by cytokines, mitogen-activated protein kinase (MAPK), integrin signalling pathway or by bone morphogenetic protein-2 [39-41]. Hocking et al. indicated that autophagy plays a role during osteoblast differentiation, mineralisation and bone homeostasis, but it is not yet clear whether inhibition or activation of autophagy promotes bone formation [42]. It is well documented that autophagy plays an essential role in embryogenesis, maintenance of tissue homeostasis, elimination of damaged subcellular structures, but also could be a mode of physiological cell death $[43,44]$. On the other hand, autophagy might be associated with cell differentiation process [45-47].

Recently, we reported a pioneering work on the role of autophagy in the osteoblast differentiation process [12]. It has been found that rough topographies of titanium-based materials obtained by anodic oxidation under spark discharge (Ticer and 3 analogue white surfaces) and acid etched (SS) induced osteoblast differentiation via autophagic PI3/Akt dependent signalling pathway. There are very sparse in vitro studies with Ti-SLA, Ti-SLActive and TiZr-SLActive surfaces. However, the results of clinical practice demonstrated that Ti-SLActive and TiZr-SLActive surfaces facilitated reduction of primary healing time decreasing it from six months to six weeks and provided a rapid loading of implants $[15,17]$. All these data encouraged us to explore whether this phenomenon could be explained by the results of some in vitro studies. In addition, the effects of TiZr-alloy (SLActive surface) on osteoblast response were examined and compared with those obtained using Ti-based materials. Thus, the aim of the present study was to evaluate surface topography effects of several surfaces widely and successfully employed in clinical practice such as Ti-SLA, Ti-SLActive and TiZr-SLActive surfaces on osteoblast proliferation and morphology and on expression of bone sialoprotein (BSP), osteocalcin (OC), collagen type I (Col-1) and endogenous nitric oxide (NO). The role of autophagy in osteoblast differentiation on these materials was also explored.

\section{Materials and Methods}

\subsection{Materials}

The reference material Ticer and Ti $\mathrm{cp}$, as well as Ti-SLA, Ti-SLActive, TiZr-SLActive and Cercon were kindly obtained from ZL Microdent, Germany and Institut Straumann AG, Basel, Switzerland, respectively.

\subsection{Cell Isolation and Culture}

All procedures employed in this study were approved by the Ethics Committee of the University of Leipzig (No. 086-2008) and performed according to the rules of the Declaration of Helsinki from 1975 (revised in 1983). Human mandibular bone samples without any clinical or radiographic pathological evidence were obtained from three male donors undergoing lower wisdom tooth surgery at the Department of Oral, Maxillary, Facial and Reconstructive Plastic Surgery at the University Hospital of Leipzig. The bone samples and cell isolation were performed as described previously [48]. Afterwards, the cells were subcultured from initially isolated primary cells and seeded in chamber slides (Nunc ${ }^{\mathrm{TM}}$ Lab-Tek $^{\mathrm{TM}}$ II Chamber Slide ${ }^{\mathrm{TM}}$ System, Thermo Scientific ${ }^{\mathrm{TM}}$ Nalgene $^{\mathrm{TM}}$; Darmstadt, Germany; 2000 cells/well) or 96-well plates (20,000 cells/well) containing Ti cp, Cercon, Ticer, Ti-SLA, Ti-SLActive and TiZr-SLActive. All experiments were performed in triplicate.

\subsection{DAPI Staining of the Cells}

Cells attached to the investigated materials from the eight chamber slides were rinsed several times with PBS. Then, the cell nuclei were stained with 4,6-diamidino-2-phenylindole dihydrochloride (DAPI; Serva, Heidelberg, Germany) and cell proliferation was determined as the number of cells on the investigated surfaces [49]. 


\subsection{Acridin Orange Staining-Microscopy}

The cells were allowed to grow on different materials for 2, 5, 7 and 10 days and stained with acridine orange (AO, $15 \mu \mathrm{L}, 3 \mu \mathrm{g} / \mathrm{mL}$ ). A motorized Zeiss Axiophot2 microscope (Zeiss, Oberkochen, Germany) equipped with the appropriate filter (Semrock Inc., Rochester, NY, USA, FF01-500/LP-25 $500 \mathrm{~nm}$ blocking edge BrightLine ${ }^{\circledR}$ (Huntingdon, UK) long-pass filter transmission band 1519-700 nm) was used for analyses. The cell morphology was determined as previously described [48]. In short, cell morphology was evaluated by measuring the footprint area of the cell on the surface after attachment and using a shape factor, $\phi=(4 \pi A) / p^{2}(A=$ footprint area; $p=$ the perimeter of the cell).

\subsection{BSP, OC and Col-1 Expression}

Eight chamber slides with the osteoblast cells were removed from the incubator after 2, 5, 7 or 10 days and the cells were fixed in paraformaldehyde (4\% PFA in PBS) for $15 \mathrm{~min}$ and rinsed in PBS. The attached cells were treated for $2 \mathrm{~h}$ with $10 \%$ normal goat serum (Vector, Burlingame, CA, USA) in PBS and incubated overnight at $4{ }^{\circ} \mathrm{C}$ with 1:100 diluted primary antibody against BSP (monoclonal, mouse-anti-human; Immundiagnostik AG, Bensheim, Germany) or osteocalcin (monoclonal, mouse-anti-human; Acris, Hiddenhausen, Germany) or Col-1 (Acris Antibodies GmbH, Herford, Germany). After washing in PBS, the bound primary antibodies were visualized by incubation for $2 \mathrm{~h}$ with 1:50 (BSP, OC) or 1:200 (Col-1) diluted goat-antirabbit-Cy3 (Jackson Immuno Research, West Grove, PA, USA) in PBS containing $2 \%$ bovine serum albumin (Serva). After rinsing several times in PBS, cell preparations were counterstained using DAPI (Serva) and coverslipped. Zeiss Axiophot2 microscope equipped with the appropriate filters (DAPI: Zeiss, Filter Set 01 (488001-9901-000) excitation 365/12 nm emission 397 nm; Cy3: Zeiss, Filter Set 43 HE (489043-9901-000) excitation 550/25 nm emission $605 / 70 \mathrm{~nm}$ ) were used for visualization.

\subsection{Acridin Orange Staining-Flow Cytometry}

For flow cytometric analyses after 24 and $48 \mathrm{~h}$, cells were trypsinized, collected and conducted to further evaluation. Detached cells were stained with $1 \mu \mathrm{M}$ AO for $15 \mathrm{~min}$ at $37^{\circ} \mathrm{C}$. At the end of incubation period, the cells were washed and resuspended in PBS. Cells were analyzed (excitation 488 nm, emission 650 nm) on Partec FloMax ${ }^{\circledR}$ software (version 2.82, Partec GmbH, Münster, Germany). Compensation was not used. In total, 20,000 events were analyzed.

\subsection{NO Production-Flow Cytometry}

For intracellular NO detection, cells were trypsinized, washed and incubated for $1 \mathrm{~h}$ at $37^{\circ} \mathrm{C}$ with $1.5 \mu \mathrm{M}$ of NO indicator DAF-FM (4-amino-5-methylamino- $2^{\prime}, 7^{\prime}$-difluorofluorescein) diacetate (Molecular Probes) in phenol red and serum-free medium. Then the cells were washed in PBS and incubated for additional $15 \mathrm{~min}$ at $37{ }^{\circ} \mathrm{C}$ in phenol red free medium for deesterification of the intracellular diacetates. Finally, the cells were resuspended in PBS and analyzed (excitation $488 \mathrm{~nm}$, emission 495/515 nm) by CyFlow ${ }^{\circledR}$ (Partec GmbH, Münster, Germany) Space Partec using the Partec FloMax ${ }^{\circledR}$ software (Partec GmbH, Münster, Germany).

\subsection{Reactive Oxygen Species/Reactive Nitrogen Species (ROS/RNS) Production-Flow Cytometry}

The production of ROS/RNS was determined by redox-sensitive dye, dihydrorhodamine 123 (DHR). The cells were stained with $1 \mu \mathrm{M}$ DHR for $20 \mathrm{~min}$ before exposure to materials. After 24 or $48 \mathrm{~h}$ of incubation, they were detached, washed with PBS, and the fluorescence intensity was analyzed with CyFlow ${ }^{\circledR}$ Space Partec using the Partec FloMax ${ }^{\circledR}$ software.

\subsection{Statistical Analysis}

Data from the repeated experiments are presented as the mean and standard deviation. The significance of the differences between various treatments was assessed by ANOVA followed 
by the Student-Newman-Keuls test. Differences were considered significant if the $p$ value was lower than 0.05 .

\section{Results}

\subsection{Cell Proliferation}

Several different topographies employed clinically as dental implants were used in this study: Ti cp, Cercon, Ticer, Ti-SLA, Ti-SLActive and TiZr-SLActive. Ti cp (smooth titanium surface) and Ticer (rough titanium surface obtained by anodic spark deposition) served as the controls, because they were investigated in vitro as reported earlier [21,48]. Additionally, smooth topography material based on zirconia (Cercon) was used for comparison. Although Ti-SLA, Ti-SLActive and TiZr-SLActive topographies have been investigated in vivo and in clinical practice [50-55], studies on human primary cells are still limited [56-59]. Osteoblast cells were allowed to proliferate on the investigated implant surfaces up to 10 days and evaluated by the DAPI assay (Figure 1). After only 2 days of cultivation, a significantly higher number of the cells was found on Ti cp, Cercon, and Ticer than on Ti-SLA, Ti-SLActive and TiZr-SLActive. The highest osteoblast proliferation was observed on day 2 of cultivation on Cercon, followed by Ti cp, and these values significantly differed from those found on other surfaces. In direct comparison of Ticer, Ti-SLA, Ti-SLActive and TiZr-SLActive surfaces, on days 7 and 10, cell number was significantly increased only on Ti cp and Cercon. Moreover, proliferation was significantly lower on Ti-SLActive and TiZr-SLActive than on Ticer or Ti-SLA.

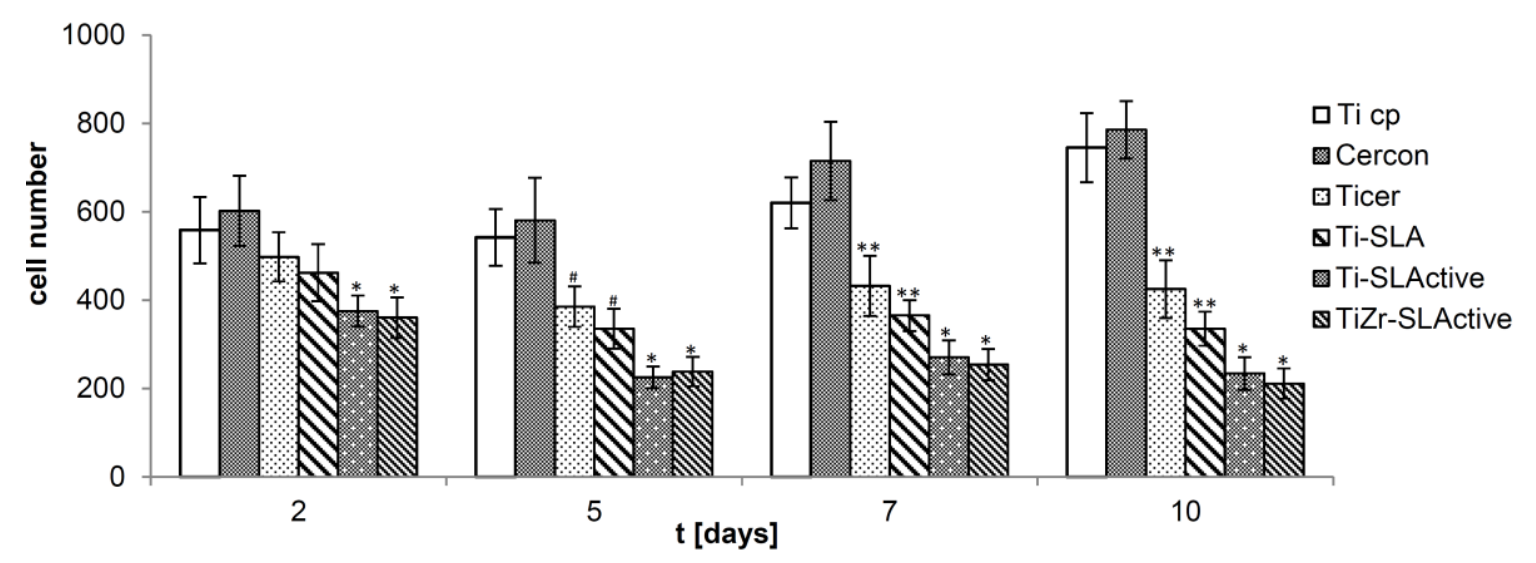

Figure 1. Proliferation of osteoblasts on various clinically employed surfaces $\left({ }^{*} p<0.05 \mathrm{vs}\right.$. Ti $\mathrm{cp}$, Cercon, Ticer, Ti-SLA; ${ }^{\#} p<0.05$ vs. Cercon; ${ }^{* *} p<0.05$ vs. Ti cp, Cercon).

\subsection{Cell Morphology}

The influence of the investigated materials on the osteoblast morphology was explored for up to 10 days of incubation (Figure 2). During the investigated time, osteoblasts grown on the Ti cp and Cercon were exclusively fully spread and exhibited flattened morphology, lying parallel to each other, indicating no influence of the smooth topographies under experimental conditions applied. Contrary to that, the cells did not lie parallel to each other on rough surfaces, but appeared as building groups-cell clusters with changed morphology. Explicitly, in accordance with previously reported results [48], on Ticer and Ti-SLA surfaces, osteoblast morphology changed to polygonally shaped cells from day 2 to 10 (some $20 \%$ to $70 \%$ of the cell population). Interestingly, on day 2 of the experiment, only $65 \%$ and $55 \%$ of the cells on Ti-SLActive and TiZr-SLActive, respectively, were flattened, while from day 5 on, only polygonal cells were recorded on these two surfaces, however there were two different types of polygonal cells. 


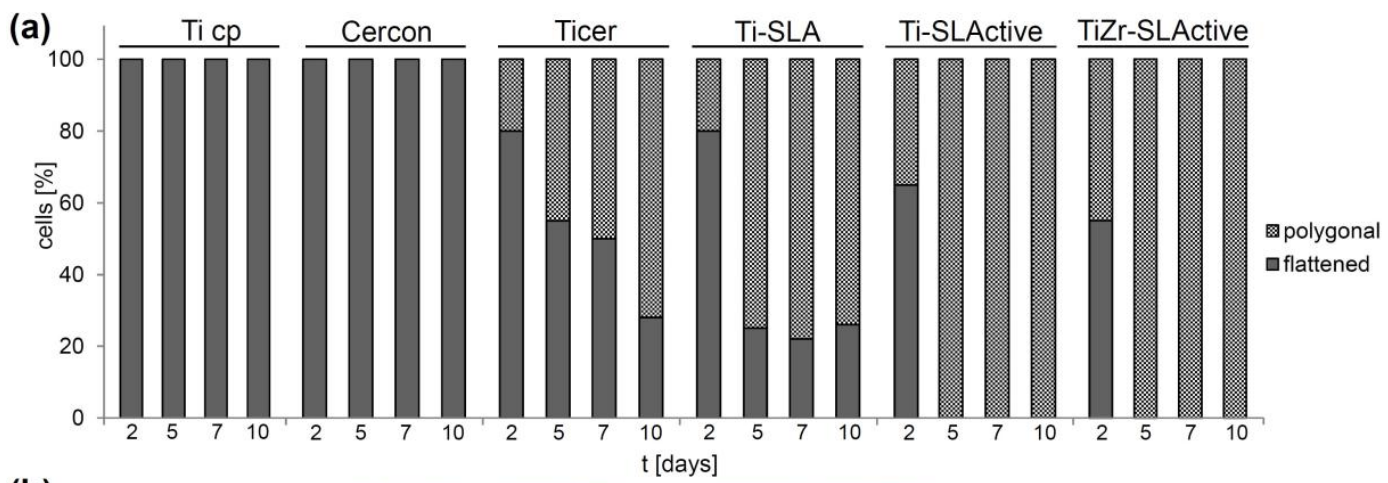

(b)
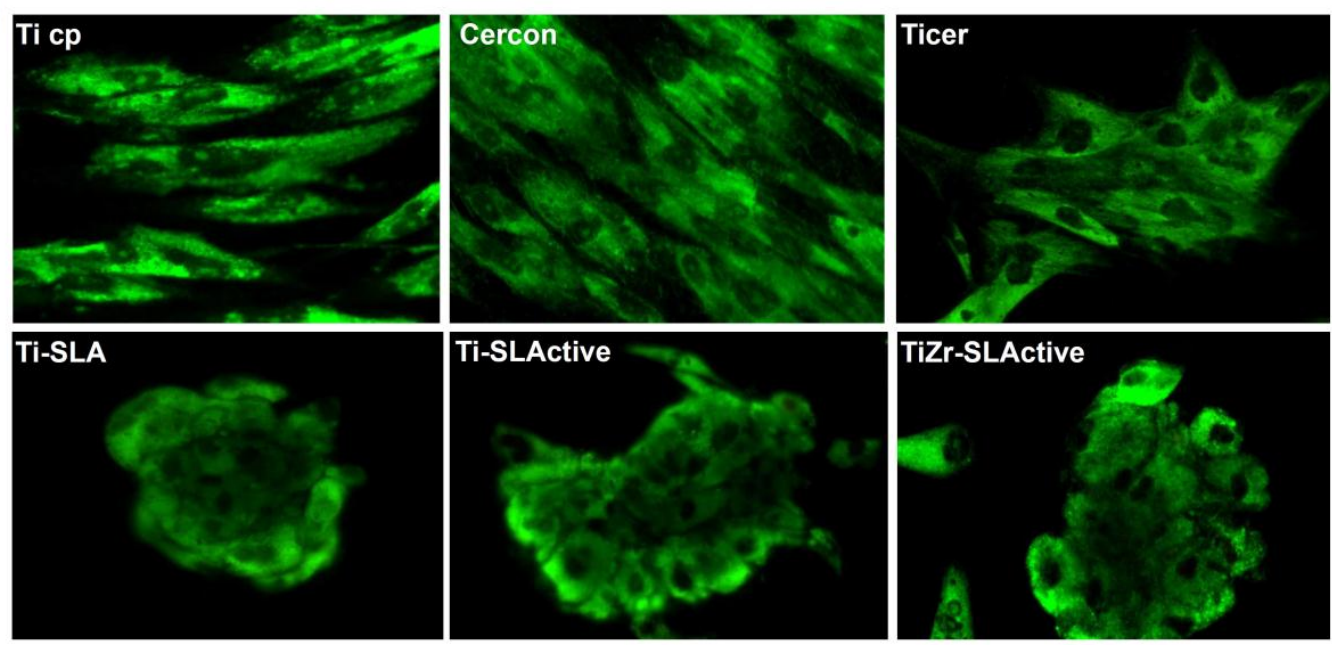

Figure 2. (a) Osteoblast footprint area on different surfaces after 2, 5, 7 and 10 days of seeding; (b) Microphotographs of osteoblast morphology after 10 days of seeding.

\subsection{Cell Cluster Formation}

Clustering of the cells was investigated after $48 \mathrm{~h}$ of osteoblast cultivation on the investigated surfaces. The cells were homogenously spread on the Ti cp, Cercon, Ticer and Ti-SLA, while already being organized in clusters on Ti-SLActive and TiZr-SLActive. After $96 \mathrm{~h}$ of culture, cell clusters were also observed on Ticer and Ti-SLA surfaces (Figure 3).

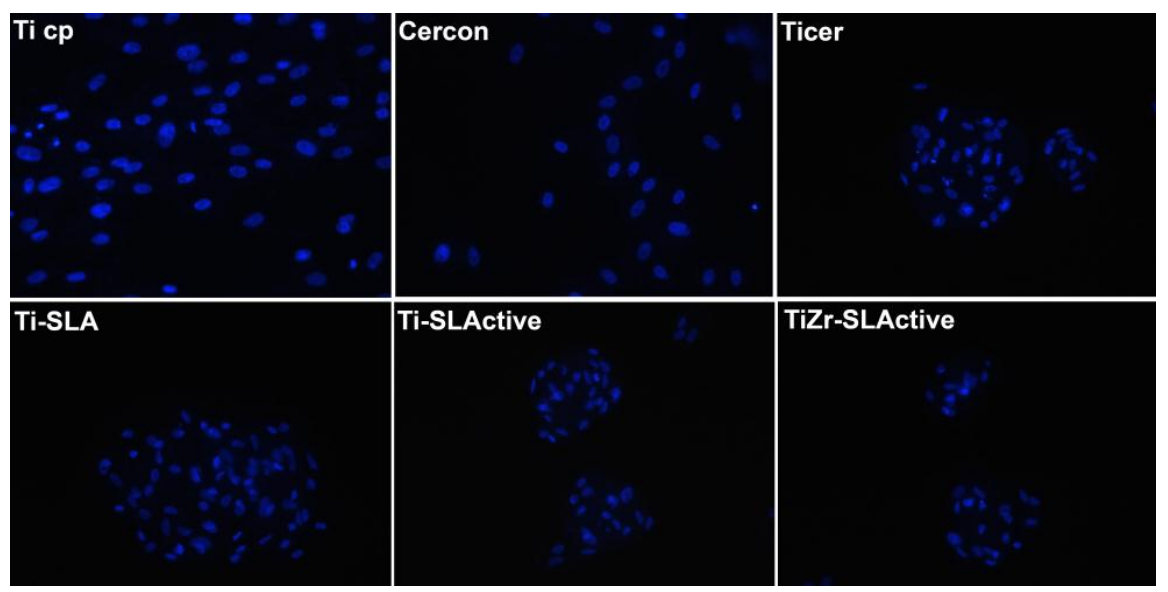

Figure 3. The effect of surfaces on cell cluster formation ( 5 days of culture, propidium iodide (DAPI staining). 


\subsection{Osteocalcin, Bone Sialoprotein and Collagen Type I}

Immunocytochemistry was applied to detect and quantify OC, BSP and Col-1 production in osteoblasts incubated on different surfaces. During the differentiation phase, osteoblasts deposit protein matrix on the surfaces. This is characterized by upregulation of OC, BSP and Col-1 (Figure 4). Similar expressions of OC, BSP, and Col-1 were detected in osteoblasts on Ti cp, Cercon, Ticer and Ti-SLA on day 2 of culture, while osteoblasts grown on Ti-SLActive and TiZr-SLActive surfaces already expressed a significantly higher production rate of the mentioned molecules. The highest production of all examined species was recorded on day 5 of culture on Ti-SLActive and TiZr-SLActive, while the peak production on Ticer and Ti-SLA was detected on day 10 of the experiment.
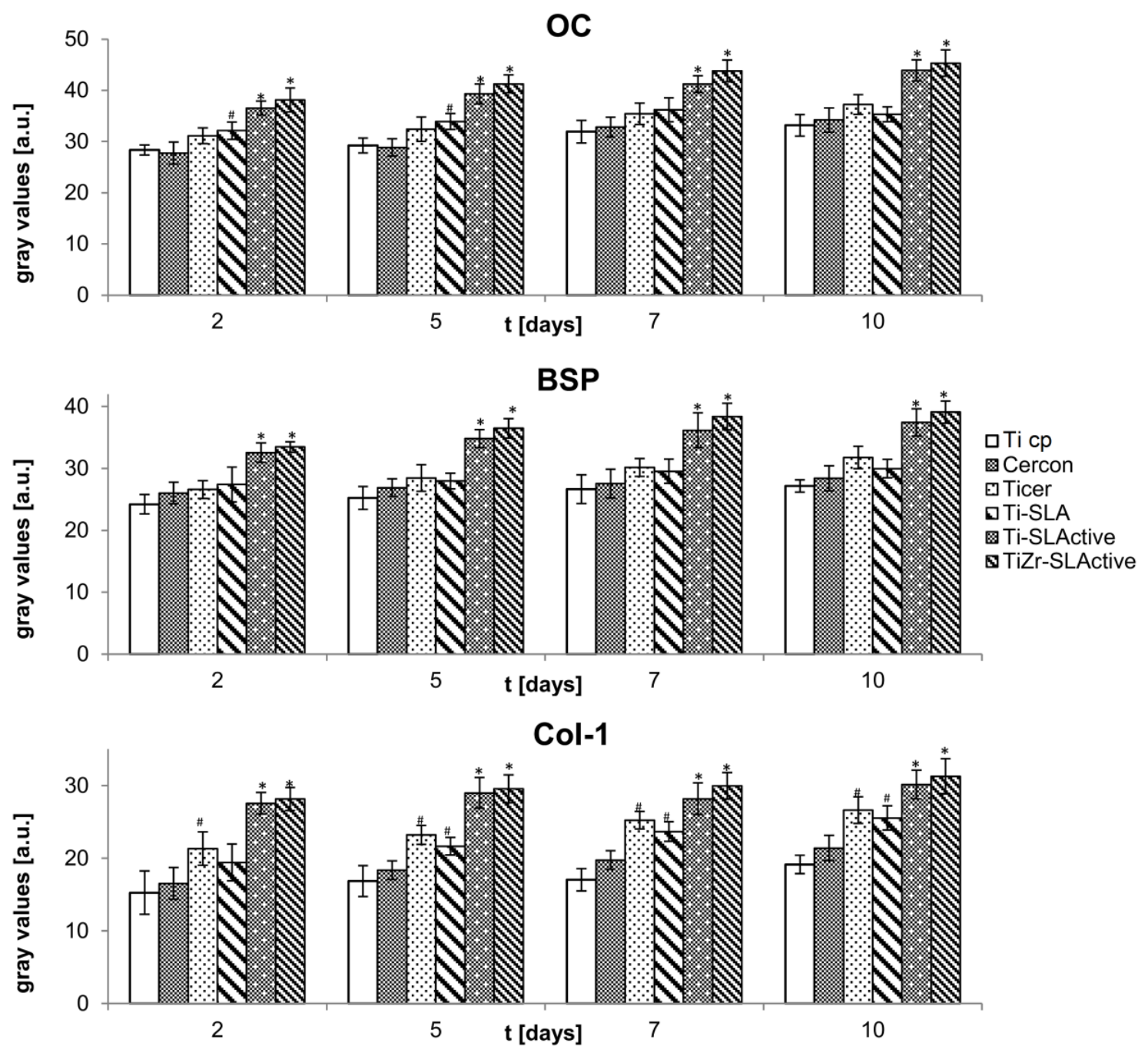

Figure 4. Time dependent production of osteocalcin (OC), bone sialoprotein (BSP) and collagen type I (Col-1) on various surfaces ${ }^{*} p<0.05$ vs. Ti cp, Cercon, Ticer, Ti-SLA; ${ }^{*} p<0.05$ vs. Ti cp, Cercon).

\subsection{Production of NO and ROS/RNS in Large Granular Cells}

DAF-FM diacetate and DHR stainings were employed for detection of NO and ROS/RNS [60-63]. Osteoblasts were cultivated on six surfaces of different topographies and intracellular levels of $\mathrm{NO}$ and ROS/RNS were examined. Only large granular cells (FSC high/SSC high) produced both enhanced intracellular NO and ROS/RNS levels (Figure 5). On the other hand, low granular small cells (FSC low/SSC low) showed no enrichment either in NO or in ROS/RNS amount. The production of both $\mathrm{NO}$ and ROS/RNS depended on the specificity of the surface itself. A high amount of NO in large 
granular cells was observed in cultures grown on Ti-SLActive and TiZr-SLActive to be followed by Ticer and Ti-SLA. Ti cp and Cercon triggered the lowest NO production in comparison with other surfaces examined here. Similar to NO detection results, the level of ROS/RNS species was also significantly higher in large granular cells than in small granular ones (Figure 5b). However, a higher amount of ROS/RNS was observed in the cells incubated on Ticer, Ti-SLA, Ti-SLActive and TiZr-SLActive in comparison with Ti cp and Cercon.

(a)
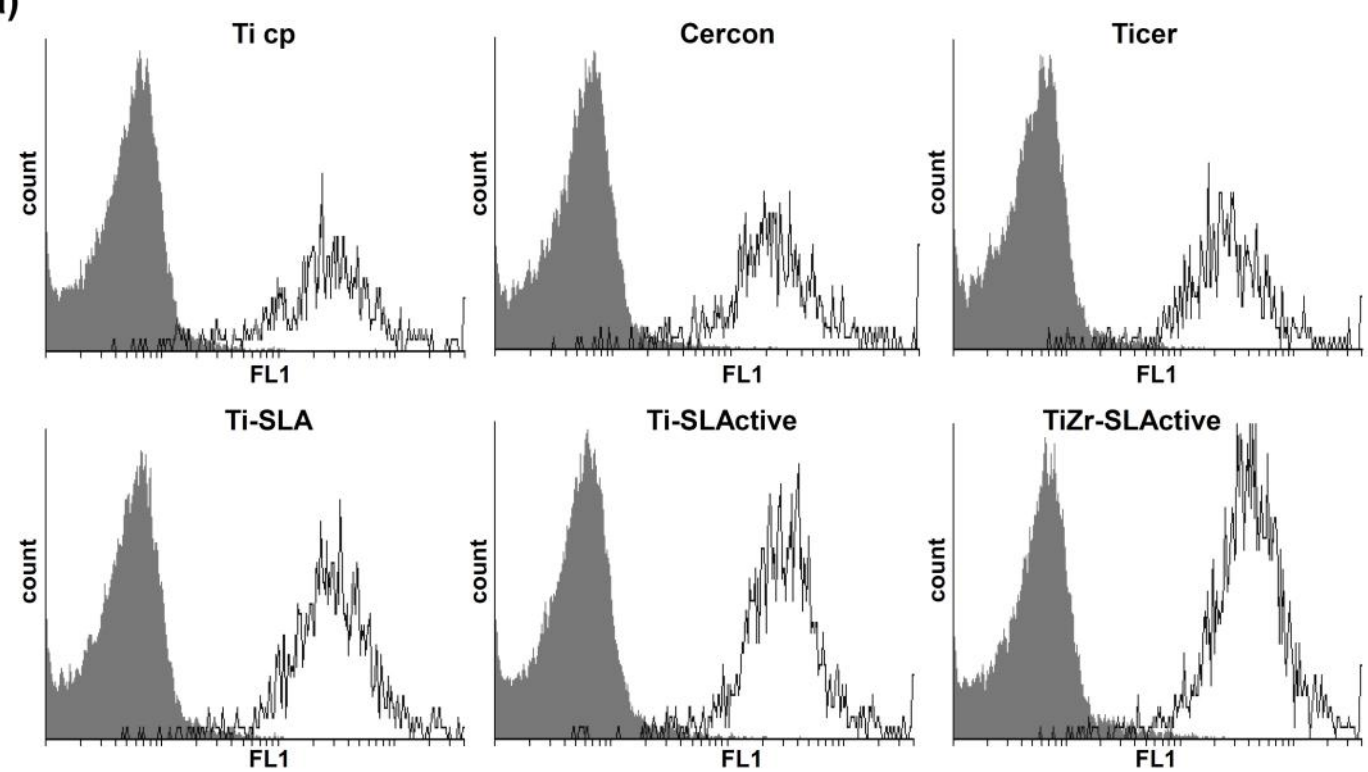

(b)
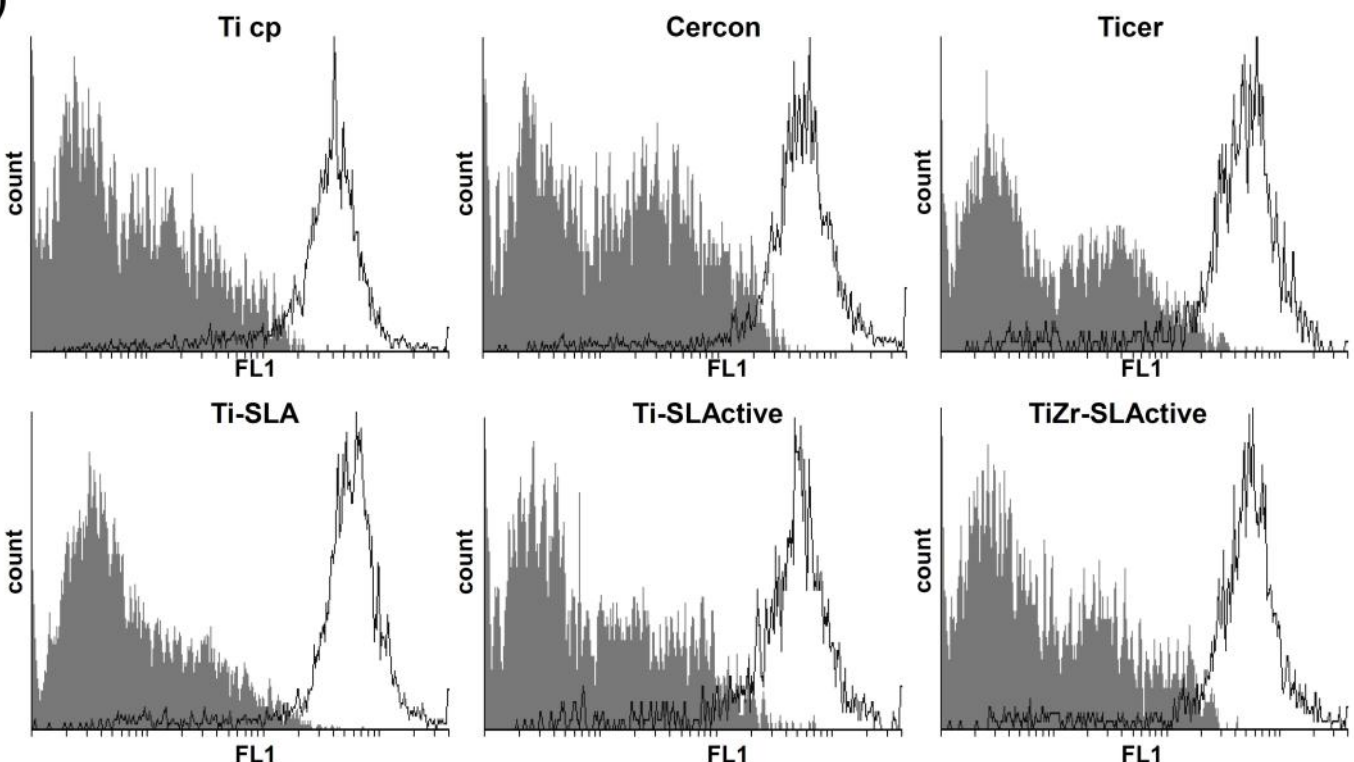

Figure 5. (a) NO and (b) ROS/RNS expression of cells grown on different surfaces (DAF-FM diacetate

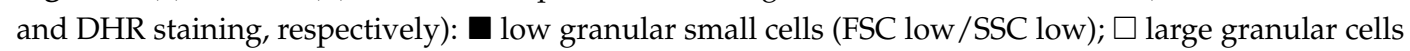
(FSC high/SSC high).

\subsection{Autophagy Induction}

To find out whether autophagy is involved in the observed morphological changes and cell cluster formation, the cells were cultivated for 24 and $48 \mathrm{~h}$ in the presence of six different surfaces and $\mathrm{AO}$ staining was subsequently performed. $\mathrm{AO}$ is staining the autophagosomes, the hallmark of the 
autophagy process, exhibiting green to red fluorescence, depending on medium acidity $[64,65]$. Cell size and granularity were determined by flow cytometric analysis [66,67]. After only $24 \mathrm{~h}$ of osteoblast growth on the surfaces used here, small cells of low granularity and without autophagy were the most abundant population (FSC low/SSC low; Figure 6a). On the other hand, intensified autophagy was observed in larger cells with high granularity (FSC high/SSC high; Figure 6b). At least three times more of such cells were recorded on Ti-SLActive and TiZr-SLActive topographies (FSC high/SSC high; Figure $6 \mathrm{a}$ ) than on other surfaces. After $48 \mathrm{~h}$ of culture, a discrete subpopulation of smaller, granular cells exhibiting less autophagy than the cells from the other subpopulation, were observed only on Ti-SLActive and TiZr-SLActive surfaces (Figure 7).

(a)
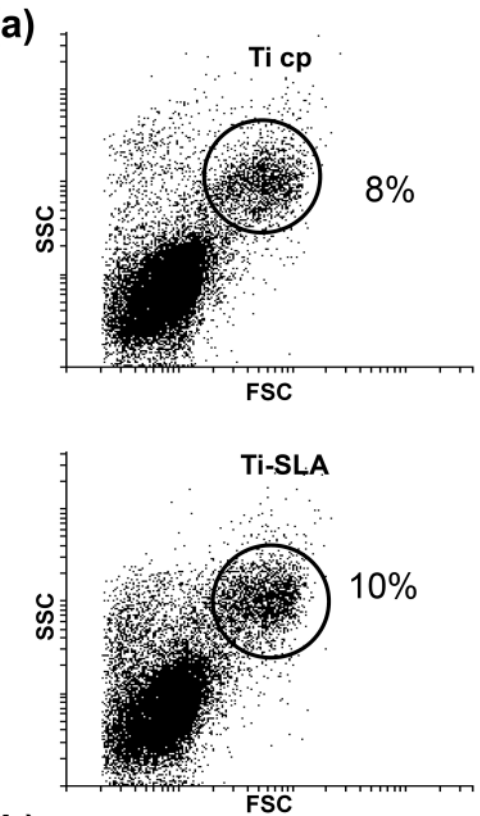

(b)
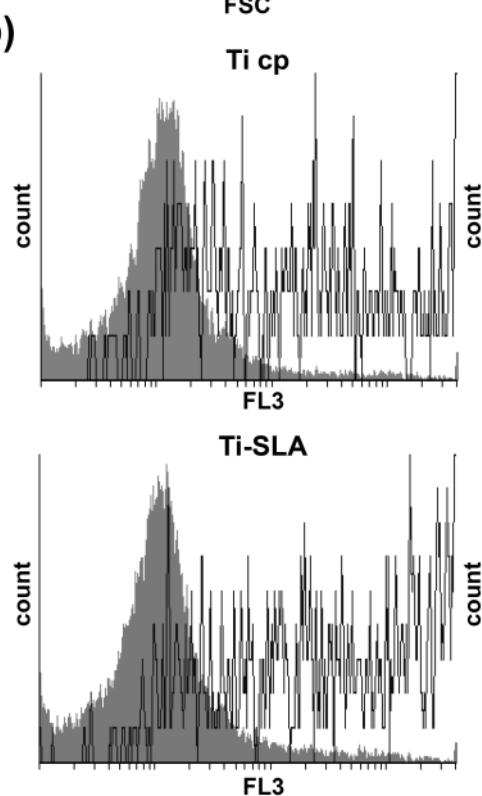

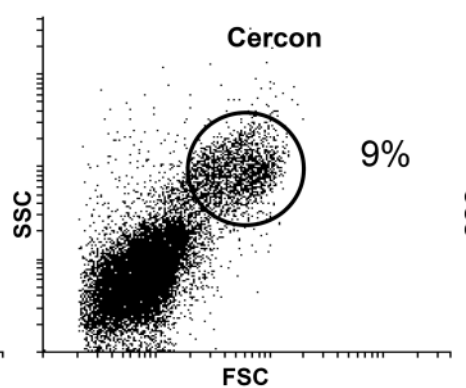

FSC

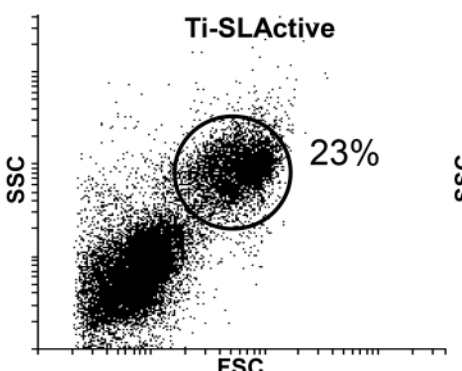

Cercon

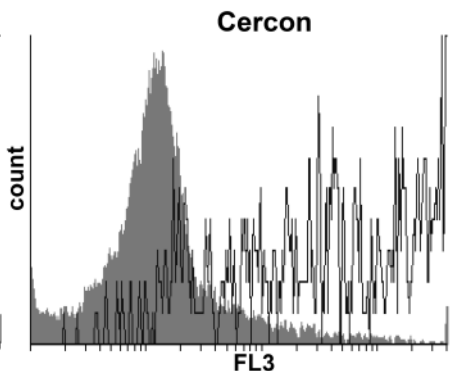

Ti-SLActive

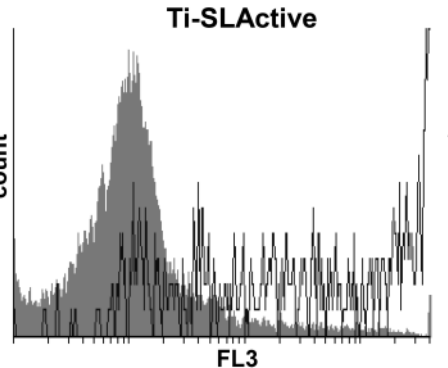

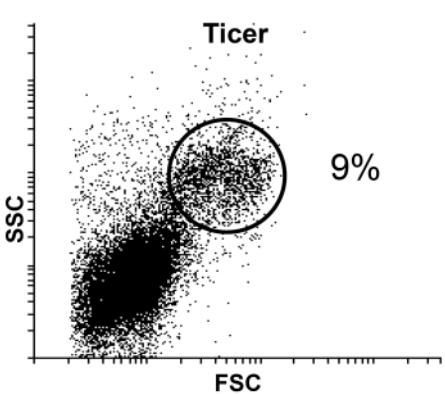

TiZr-SLActive

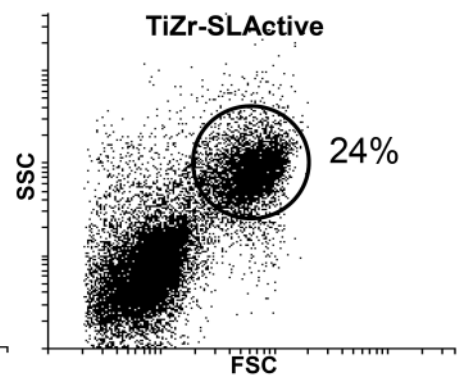

Ticer

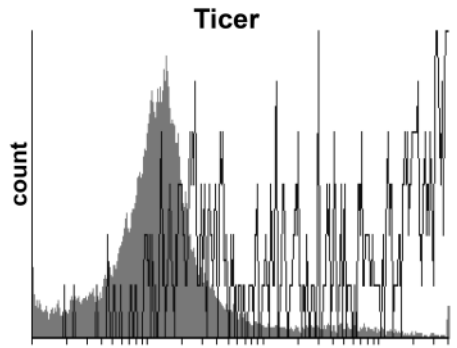

FL3

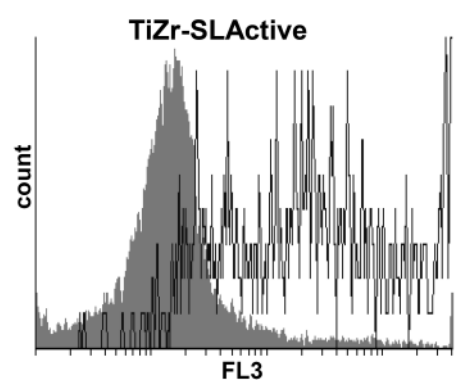

Figure 6. Presence of autophagosomes in a discrete population of osteoblasts cultivated $(24 \mathrm{~h})$ on the investigated surfaces. (a) Distribution of cells by size/granularity; (b) acridine orange (AO) staining, cells were analyzed by flow cytometry: $\mathbf{\square}$ low granular small cells (FSC low/SSC low); $\square$ large granular cells (FSC high/SSC high). 

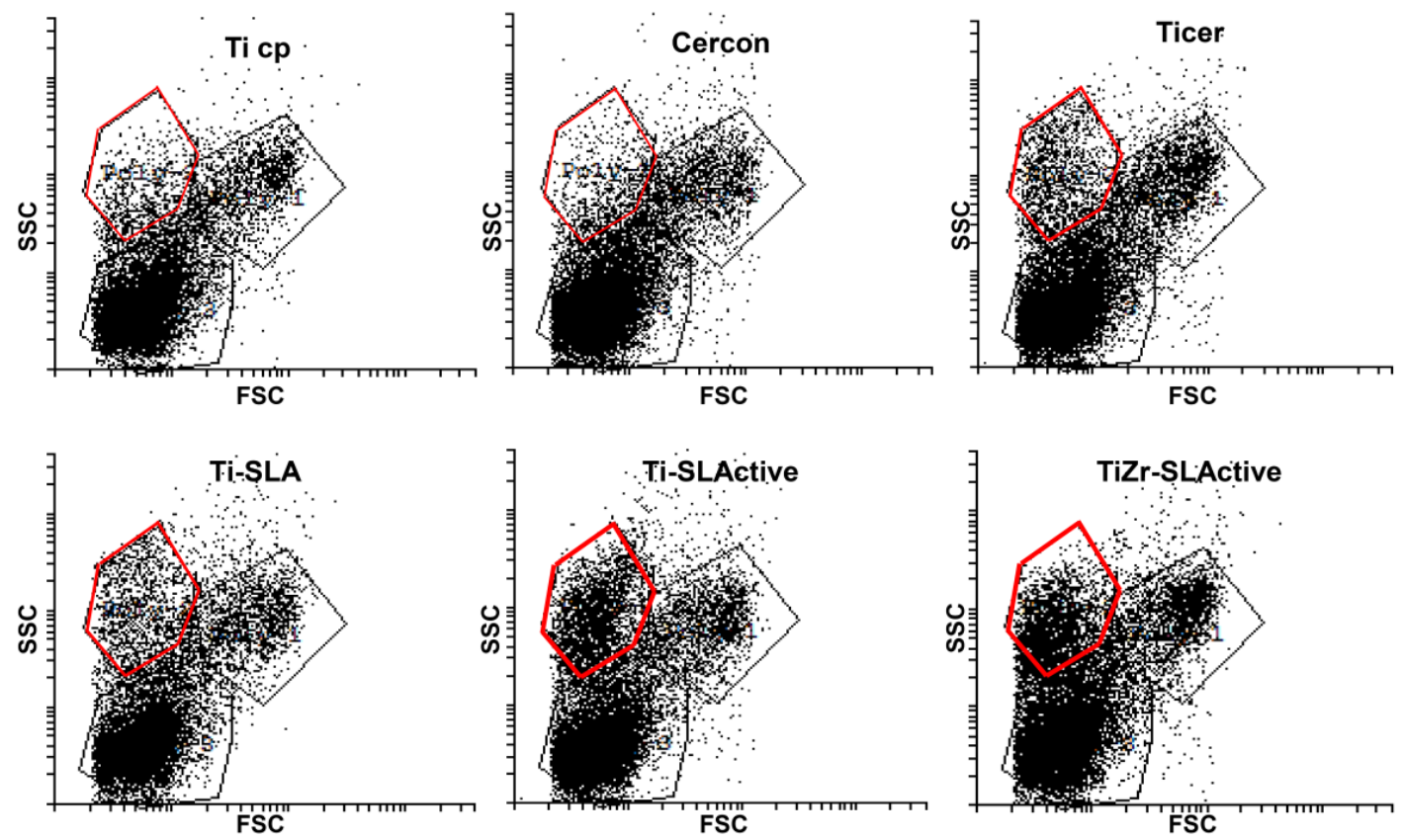

Figure 7. Distribution of cells by size/granularity in the presence of different implant materials ( $48 \mathrm{~h}$ of cultivation; 3rd distinctive population is highlighted in red color).

\section{Discussion}

Recently, it was elucidated that autophagy plays an important role in osteoblast differentiation when cultivated on anodical titanium-based topographies [12]. In addition to three white novel titanium-based surfaces, Ticer, a clinically used surface, was employed in the previously reported study. In order to find out whether chemical composition of dental implant surfaces affects osteoblast differentiation, Ti-SLA, Ti-SLActive and TiZr-SLActive (all rough; $R_{\mathrm{a}}=1.5,1.6$ and $1.6 \mu \mathrm{m}$, respectively) [68,69] materials, as well as Cercon (smooth; $R_{\mathrm{a}}<0.2 \mu \mathrm{m}$ ), zirconia material, were selected for the present study. Ti cp (smooth; $R_{\mathrm{a}}<0.2 \mu \mathrm{m}$ ) and Ticer (rough; $R_{\mathrm{a}}=1.4 \mu \mathrm{m}$ ) [22] titanium-based surfaces (investigated previously) [12], served as controls. The results of this work will confirm and extend the hypothesis that surface topography, as well as the composition of dental implants influence not only cell proliferation, but also morphology and expression of BSP, OC and Col-1 of osteoblasts.

As observed previously, cell proliferation was increasing during the investigated time period only on Ti cp and Cercon surfaces $[21,48]$. However, a similar cell proliferation rate was recorded on Ti cp, Cercon, Ticer and Ti-SLA on day 2 of incubation. From day 5 of culture on Ticer and Ti-SLA, number of the cells was significantly lower compared to those observed on two smooth surfaces (Ti cp and Cercon). Interestingly, a significantly lower number of the cells was noticed in all investigated time points on Ti-SLActive and TiZr-SLActive surfaces.

Osteoblast proliferation was found to be influenced by surface roughness (Figure 1) [70], while chemical composition of the surface seems to express additional effects. The results of the present study are in accordance with earlier findings demonstrating that acid etched (e.g., Ti-SLA) as well as anodically oxidized surfaces (e.g., Ticer) resulted in low cell proliferation rate. However, clinical practice showed that dental implants with such surfaces exhibit fast osseointegration and improved bone to implant contact [71,72]. It is obvious that smooth Ti $\mathrm{cp}$ and Cercon surfaces induced proliferation of the cells. Materials promoting cell proliferation are mainly unsuitable for cell differentiation $[73,74]$. However, our results showed that the number of osteoblasts remained almost constant from day 5 of cultivation on rough surfaces such as Ticer, Ti-SLA, Ti-SLActive and TiZr-SLActive. 
Discrepancies in cell proliferation rate on materials of various topographies were evident already from day 2 of incubation. Interestingly, such cell behavior was also accompanied with morphology changes and affected biochemical parameters of the examined protein expressions. As expected, smooth surfaces such as Ti cp and Cercon caused no alteration in osteoblast morphology up to day 10 of experiments. However, Ti-SLActive and TiZr-SLActive surfaces highly affected cell morphology and already on day 2 of cultivation at least $35 \%$ cells exhibited polygonal morphology, while from day 5 on, only polygonal cells were identified. This effect was not so prominent in the cells cultivated on Ticer and Ti-SLA. Thus, on day 3 of culture, only $20 \%$ and on day 10 at least $70 \%$ of cells were polygonally shaped. Cell shape represents one of the most important regulators of proliferation rate and differentiation and division of polygonally shaped cells proceeds by a much lower rate in relation to that of well spread flattened cells [21]. Polygonally (rounded) configured osteoblasts point toward a high synthetic activity of the cells. Influence of the fast morphological changes (flattened $\rightarrow$ polygonal) is considered to be a positive influence of material.

The observed cell response differences related to the investigated surface topographies could be connected to cell morphology alterations (activation of signaling pathways, gene expression, differentiation, cell shape, motility, etc). Furthermore, changes in the extracellular matrix trigger the pathways that affect growth and phenotype differentiation [75]. The cells cultivated on various materials examined here showed an enhanced production of OC, BSP and Col-1 with the exception of Ti cp and Cercon. It seems that Ti-SLActive and TiZr-SLActive surfaces stimulate expression of several biochemical markers of osteoblast differentiation much faster than Ticer or Ti-SLA. Osteoblast differentiation is accompanied by upregulation of OC, BSP and Col-1 [76-78]. As one of the most specific markers of mature osteoblasts [76,77], OC plays an important role in the bone matrix formation. Enhanced BSP levels are present in early stages of bone maturation [48,79]. Moreover, BSP acts as a nucleator for mineralization in bone [80]. Cell growth on collagen gels acts by inducing rapid differentiation of osteoblastic cells [75]. Thus, the enhancement of Col-1 formation in the extracellular matrix could be interpreted as an indicator of the osteoblast differentiation process reported here. This is in accordance with the abovementioned results showing that Ticer, Ti-SLA, Ti-SLActive and TiZr-SLActive act by promoting osteoblast differentiation expressed as irregular and polygonal cellular morphology and increased levels of key proteins related to the osteogenic phenotype [81].

In addition to significant material topography-related differences observed here not only in proliferation rate but also in morphological appearance and protein expression of osteoblast cells, discrepancies in cell cluster formation were detected as well. As previously shown using Ti cp [12], cell cluster formation was not observed throughout the present study when smooth surface materials such as Cercon and Ti cp were applied. Also, no variation in cell size in either morphology was observed. Thus, cells exhibited flattened morphology, were well spread and laid parallel to each other indicating good attachment. Contrary to that, on Ti-SLActive and TiZr-SLActive surfaces on day 2, migrations of cells and cell clustering were observed. Those clusters were exclusively formed from the small polygonal cells, highly differentiated ones, presenting the next step in the process of osteoblast maturation, as reported previously [12]. On Ticer and Ti-SLA, cell clusters were formed on day 5 of culture. Cell clusters are essential for osseointegration because they are precursors of bone noduli formation [12]. Lundberg et al. showed that bone-relevant biological molecules (e.g., vasoactive intestinal peptide) hinder mouse calvariae osteoblast proliferation and enhance differentiation rates of committed noduli-forming cells [82]. Moreover, it was reported that autophagy exhibits a crucial effect on osteoblast function related to its role in supporting osteoblast noduli formation [83]. In order to investigate whether autophagy is connected to cell cluster formation, 3MA, an autophagy inhibitor, was added to the osteoblasts cultured on surfaces differing in topography. Our results showed that 3MA prevented cluster formation of osteoblast cells (data not shown). This is consistent with our recently reported results [12]. It was also shown that treatment with autophagy inhibitors in vivo led to defective osteoblast noduli formation [83]. 
Flow cytometric analysis of autophagy after $24 \mathrm{~h}$ of osteoblast cultures revealed the presence of two discrete cell subpopulations. The first subpopulation consisted of cells with low granularity and low autophagy, namely osteoblasts. The second subpopulation included remarkably larger, highly granulated cells with intensified autophagic processes, i.e., mature osteoblasts were observed. After $48 \mathrm{~h}$ of culture, the third cell subpopulation was identified only when Ti-SLActive and TiZr-SLActive surfaces were used. Morphologically, these cells can be classified as smaller and granular cells. Nevertheless, these cells showed lower autophagy levels in relation to the second cell subpopulation. Using fluorescence microscopy, small and polygonal cells were also detected on Ti-SLActive and TiZr-SLActive as early as day 2 of culture. This could be the same type of cell (third subpopulation) identified with flow cytometry. In the process of osteoblast maturation, this subpopulation represents the next step. As reported earlier [12], osteoblasts have to grow for at least $72 \mathrm{~h}$ on Ticer to visualise the third cell subpopulation. Consequently, depending on the topography and composition of the surface, distinctive kinetics of this process take place within the cells.

Increased OC production recorded in cells cultivated on Ti-SLActive and TiZr-SLActive, apart from Ticer and Ti-SLA, could be connected to the activation of PI3/Akt signalling pathway, which is responsible not only for autophagy activation but also for osteoblast differentiation [42]. Pantovic et al. showed that human dental pulp mesenchymal stem cells differentiate via AMPK-induced autophagy and Akt activity to osteoblasts [84].

Production of $\mathrm{NO}$ as one of the osteoblast differentiation and maturation hallmarks was determined by flow cytometry. Flow cytometric analysis after only $24 \mathrm{~h}$ of cell culture on the investigated surfaces revealed a cell subpopulation producing enhanced NO levels. This subpopulation, consisting of large cells with high granularity, coincides with high autophagy cell subpopulations. The first subpopulation containing immature osteoblasts exhibited low NO production and a constant autophagy level.

NO plays an important role in bone homeostasis $[85,86]$. Inhibition of NO production in mice was shown to cause severe abnormalities in bone formation because of delaying osteoblast differentiation [87]. Some of the research pointed to a key role of NO in both intra- and intercellular response to mechanic stimuli [88]. As mentioned above, the second cell subpopulation containing remarkably larger cells of higher granularity had significantly increased NO levels in comparison with that found in small size cell subpopulations. It is obvious that mechanical stimulation of cell membrane by material surface promoted intracellular response mediated at least partly by enhanced NO production. This molecule is known as a modulator of numerous signalling pathways including transcriptional pathways (e.g., YY1, SP11 ... ), thus regulating proteins and genes involved in cell proliferation, differentiation and cell death [89].

To address the question on whether stress could act as an autophagy trigger, the presence of ROS/RNS in osteoblasts grown on different surfaces was evaluated. Similar to investigations related to NO, a high quantity of ROS/RNS was identified in the second cell subpopulation. Mechanical stress might cause induction of autophagy $[90,91]$. All our results presented here contribute to the suggestion that the employed materials mechanically stimulated osteoblast maturation followed by amplified production of ROS/RNS and intracellular NO. Surface topography could be sufficiently effective in directly or indirectly causing cell stress and thus influencing osteoblasts differentiation [92]. Both $\mathrm{NO}$ and ROS/RNS might damage organelles leading to cell death. Moreover, ROS could be fatal for osteoblasts as a main factor causing cell death and several bone diseases. On the other hand, NO plays an important role as a mediator of cellular differentiation (osteoblast, osteoclast and other cells) [93]. However, in the case of the investigated surfaces, it seems that both ROS and NO species present in suitable concentrations could act by modulating key signalling pathways.

Ti-alloys have been introduced in implantology in order to improve mechanical stability. Nevertheless, biological response of these alloys has been questioned. Data presented in this study confirmed the observation from clinical practice related to efficacy of Ti-SLActive and TiZr-SLActive implant surfaces and their ability to promote fast osteoblast differentiation. Abundance of large cells 
with high granularity (FSC high/SSC high) in parallel with enhanced autophagy, high intracellular NO and ROS/RNS production in cells exposed to Ti-SLActive and TiZrSLActive indicated that composition of these materials and their surface topographies despite the chemical differences (Ti vs. TiZr-alloy, respectively) are crucial for their improved biological compatibility.

\section{Conclusions}

Findings reported herein contribute to the superiority of rough over smooth dental implant surfaces (Ti cp, Cercon) in the sense of interaction with osteoblasts. Moreover, it was shown that hydrophilic Ti-SLActive and TiZr-SLActive topographies possess advanced properties, in comparison with Ti cp, Cercon, Ticer and Ti-SLA, reflected in accelerated osteoblast differentiation. However, analogously to Ticer, Ti-SLActive and TiZr-SLActive surfaces induced a stress, reflected through ROS production, subsequently followed by NO formation. High levels of ROS/RNS and NO were only present in mature osteoblasts (highly granular, polygonally shaped cells). This cell subpopulation produced enhanced levels of OC, BSP and Col-1 and exhibited high autophagy. Taking all these results into account, it can be concluded that a faster autophagic process $(24 \mathrm{~h})$ triggered by contacts between the cells and Ti- or TiZr-based rough surfaces generates osteoblast maturation and differentiation with the involvement of PI3/Akt signalling pathway. Moreover, there is a debatable question on whether Ti or TiZr-alloy is superior as dental implant material $[3,94]$. Based on our results presented here, it can be claimed that, at least under in vitro conditions, both Ti-SLActive and TiZr-SLActive implant surfaces expressed a similar tendency of promoting fast osteoblast differentiation.

Acknowledgments: We are grateful to the ZL Microdent (Germany) and Institut Straumann AG (Switzerland) for the samples of Ti cp, Ticer, Cercon, Ti-SLA, Ti-SLActive, TiZr-SLActive surfaces. This work was supported by the ZL Microdent, Germany (grant number KF2036702SU9) and the Ministry of Science and Technological Development of the Republic of Serbia (grant number 173013).

Author Contributions: Milena R. Kaluđerović, Danijela Maksimović-Ivanić, Hans-Ludwig Graf and Sanja Mijatović conceived and designed the experiments; Milena R. Kaluđerović and Tamara Krajnović performed the experiments; Milena R. Kaluđerović, Danijela Maksimović-Ivanić and Sanja Mijatović analyzed the data; Milena R. Kaluđerović, Danijela Maksimović-Ivanić and Sanja Mijatović wrote the paper.

Conflicts of Interest: The authors declare no conflict of interest.

\section{References}

1. Branemark, P.I. Vital microscopy of bone marrow in rabbit. Scand. J. Clin. Lab. Investig. 1959, 11 (Suppl. 38), 1-82.

2. Brånemark, P.I.; Adell, R.; Breine, U.; Hansson, B.O.; Lindström, J.; Ohlsson, A. Intra-osseous anchorage of dental prostheses. I. Experimental studies. Scand. J. Plast. Reconstr. Surg. 1969, 3, 81-100. [CrossRef] [PubMed]

3. Grandin, H.M.; Berner, S.; Dard, M. A review of titanium zirconium (TiZr) alloys for use in endosseous dental implants. Materials 2012, 5, 1348-1360. [CrossRef]

4. Feng, B.; Weng, J.; Yang, B.C.; Qu, S.X.; Zhang, X.D. Characterization of titanium surfaces with calcium and phosphate and osteoblast adhesion. Biomaterials 2004, 25, 3421-3428. [CrossRef] [PubMed]

5. MacDonald, D.E.; Rapuano, B.E.; Deo, N.; Stranick, M.; Somasundaran, P.; Boskey, A.L. Thermal and chemical modification of titanium-aluminum-vanadium implant materials: Effects on surface properties, glycoprotein adsorption, and MG63 cell attachment. Biomaterials 2004, 25, 3135-3146. [CrossRef] [PubMed]

6. Jemat, A.; Ghazali, M.J.; Razali, M.; Otsuka, Y. Surface modifications and their effects on titanium dental implants. BioMed. Res. Int. 2015, 2015. [CrossRef] [PubMed]

7. Bauer, S.; Schmuki, P.; von der Mark, K.; Park, J. Engineering biocompatible implant surfaces: Part I: Materials and surfaces. Prog. Mater. Sci. 2013, 58, 261-326. [CrossRef]

8. Kim, B.-S.; Kim, J.S.; Park, Y.M.; Choi, B.-Y.; Lee, J. Mg ion implantation on SLA-treated titanium surface and its effects on the behavior of mesenchymal stem cell. Mater. Sci. Eng. C Mater. Biol. Appl. 2013, 33, 1554-1560. [CrossRef] [PubMed] 
9. Ramazanoglu, M.; Oshi, Y. Osseointegration and Bioscience of Implant Surfaces—Current Concepts at Bone-Implant Interface. In Implant Dentistry-A Rapidly Evolving Practice; Turkyilmaz, I., Ed.; InTech: Hampshire, UK, 2011, ISBN 978-953-307-658-4.

10. Elias, C.N. Factors Affecting the Success of Dental Implants. In Implant Dentistry - A Rapidly Evolving Practice; Turkyilmaz, I., Ed.; InTech: Hampshire, UK, 2011, ISBN 978-953-307-658-4.

11. Graf, H.-L.; Geu, B.; Knöfler, W.; Hemprich, A. Prospective clinical study to of the ZL-Duraplant-implant-system with Ticer-surface. Part II: Parameters of the periimplant tissue. Z. Zahnärztliche Implantol. 2002, 18, 169-176.

12. Kaluđerović, M.R.; Mojić, M.; Schreckenbach, J.P.; Maksimović-Ivanić, D.; Graf, H.-L.; Mijatović, S. A key role of autophagy in osteoblast differentiation on titanium-based dental implants. Cells Tissues Organs 2014, 200, 265-277. [CrossRef] [PubMed]

13. Knöfler, W.; Graf, H.-L.; Gröschel, T.; Löwicke, G. Zur Knochenreaktion auf Biomaterialien: II. Ergebnisse der fluoreszenzmikroskopischen Untersuchung zur Beobachtung der initialen Knochenbildung. Z Zahnärztl Implant. 1990, 6, 145-152.

14. Schwarz, F.; Herten, M.; Sager, M.; Wieland, M.; Dard, M.; Becker, J. Bone regeneration in dehiscence-type defects at chemically modified (SLActive) and conventional SLA titanium implants: A pilot study in dogs. J. Clin. Periodontol. 2007, 34, 78-86. [CrossRef] [PubMed]

15. Buser, D.; Broggini, N.; Wieland, M.; Schenk, R.K.; Denzer, A.J.; Cochran, D.L.; Hoffmann, B.; Lussi, A.; Steinemann, S.G. Enhanced bone apposition to a chemically modified SLA titanium surface. J. Dent. Res. 2004, 83, 529-533. [CrossRef] [PubMed]

16. Zöllner, A.; Ganeles, J.; Korostoff, J.; Guerra, F.; Krafft, T.; Brägger, U. Immediate and early non-occlusal loading of Straumann implants with a chemically modified surface (SLActive) in the posterior mandible and maxilla: Interim results from a prospective multicenter randomized-controlled study. Clin. Oral Implants Res. 2008, 19, 442-450. [CrossRef] [PubMed]

17. Schwarz, F.; Ferrari, D.; Herten, M.; Mihatovic, I.; Wieland, M.; Sager, M.; Becker, J. Effects of surface hydrophilicity and microtopography on early stages of soft and hard tissue integration at non-submerged titanium implants: An immunohistochemical study in dogs. J. Periodontol. 2007, 78, 2171-2184. [CrossRef] [PubMed]

18. Pilathadka, S.; Vahalová, D.; Vosáhlo, T. The Zirconia: A new dental ceramic material. An overview. Prague Med. Rep. 2007, 108, 5-12. [PubMed]

19. Aldini, N.N.; Fini, M.; Giavaresi, G.; Martini, L.; Dubini, B.; Ponzi Bossi, M.G.; Rustichelli, F.; Krajewski, A.; Ravaglioli, A.; Mazzocchi, M.; et al. Osteointegration of bioactive glass-coated and uncoated zirconia in osteopenic bone: An in vivo experimental study. J. Biomed. Mater. Res. A 2004, 68, 264-272. [CrossRef] [PubMed]

20. Josset, Y.; Oum'Hamed, Z.; Zarrinpour, A.; Lorenzato, M.; Adnet, J.J.; Laurent-Maquin, D. In vitro reactions of human osteoblasts in culture with zirconia and alumina ceramics. J. Biomed. Mater. Res. 1999, 47, 481-493. [CrossRef]

21. Kaluđerović, M.R.; Schreckenbach, J.P.; Graf, H.-L. Plasma-electrochemical deposition of porous zirconia on titanium-based dental material and in vitro interactions with primary osteoblasts cells. J. Biomater. Appl. 2016, 30, 711-721. [CrossRef] [PubMed]

22. Kaluđerović, M.R.; Schreckenbach, J.P.; Graf, H.-L. Zirconia coated titanium for implants and their interactions with osteoblast cells. Mater. Sci. Eng. C Mater. Biol. Appl. 2014, 44, 254-261. [CrossRef] [PubMed]

23. Kaluđerović, M.R.; Mändl, S.; Kohlweyer, H.; Graf, H.-L. Physical vapour deposition of zirconia on titanium: Fabrication, characterization and interaction with human osteoblast cells. J. Mater. Sci. Mater. Med. 2015, 26, 267. [CrossRef] [PubMed]

24. Lenz, S. Keramikimplantate- Zirkonimplantate- mit einer Titan- oder Titanoxidbeschichtung des intraossären Teiles. Patent EP2018878, March 2009.

25. Pommer, B.; Bucur, L.; Zauza, K.; Tepper, G.; Hof, M.; Watzek, G. Meta-Analysis of Oral Implant Fracture Incidence and Related Determinants. Available online: https://www.hindawi.com/archive/2014/263925/ abs / (accessed on 5 July 2017).

26. Badran, Z.; Struillou, X.; Strube, N.; Bourdin, D.; Dard, M.; Soueidan, A.; Hoornaert, A. Clinical performance of narrow-diameter titanium-zirconium implants: A systematic review. Implant Dent. 2017, 26, 316-323. [CrossRef] [PubMed] 
27. Asri, R.I.M.; Harun, W.S.W.; Samykano, M.; Lah, N.A.C.; Ghani, S.A.C.; Tarlochan, F.; Raza, M.R. Corrosion and surface modification on biocompatible metals: A review. Mater. Sci. Eng. C 2017, 77, 1261-1274. [CrossRef] [PubMed]

28. Gottlow, J.; Dard, M.; Kjellson, F.; Obrecht, M.; Sennerby, L. Evaluation of a new titanium-zirconium dental implant: A biomechanical and histological comparative study in the mini pig. Clin. Implant Dent. Relat. Res. 2012, 14, 538-545. [CrossRef] [PubMed]

29. Saini, M.; Singh, Y.; Arora, P.; Arora, V.; Jain, K. Implant biomaterials: A comprehensive review. World J. Clin. Cases 2015, 3, 52-57. [CrossRef] [PubMed]

30. Aljateeli, M.; Wang, H.-L. Implant microdesigns and their impact on osseointegration. Implant Dent. 2013, 22, 127-132. [CrossRef] [PubMed]

31. Jawad, S.; Barclay, C.; Whittaker, W.; Tickle, M.; Walsh, T. A pilot randomised controlled trial evaluating mini and conventional implant retained dentures on the function and quality of life of patients with an edentulous mandible. BMC Oral Health 2017, 17. [CrossRef] [PubMed]

32. Bernhard, N.; Berner, S.; De Wild, M.; Wieland, M. The binary TiZr alloy-A newly developed Ti alloy for use in dental implants. Forum Implant 2009, 5, 30-39.

33. Gittens, I.R.A.; McLachlan, T.; Cai, Y.; Berner, S.; Tannenbaum, R.; Schwartz, Z.; Sandhage, K.H.; Boyan, B.D. The effects of combined micron-/submicron-scale surface roughness and nanoscale features on cell proliferation and differentiation. Biomaterials 2011, 32, 3395-3403. [CrossRef] [PubMed]

34. Lian, J.B.; Stein, G.S. Concepts of osteoblast growth and differentiation: Basis for modulation of bone cell development and tissue formation. Crit. Rev. Oral Biol. Med. 1992, 3, 269-305. [CrossRef] [PubMed]

35. Lian, J.B.; Stein, G.S. Development of the osteoblast phenotype: Molecular mechanisms mediating osteoblast growth and differentiation. Iowa Orthop. J. 1995, 15, 118-140. [PubMed]

36. Boyan, B.D.; Batzer, R.; Kieswetter, K.; Liu, Y.; Cochran, D.L.; Szmuckler-Moncler, S.; Dean, D.D.; Schwartz, Z. Titanium surface roughness alters responsiveness of MG63 osteoblast-like cells to $1 \alpha, 25-(\mathrm{OH})_{2} \mathrm{D}_{3}$. J. Biomed. Mater. Res. 1998, 39, 77-85. [CrossRef]

37. Anselme, K.; Linez, P.; Bigerelle, M.; Le Maguer, D.; Le Maguer, A.; Hardouin, P.; Hildebrand, H.F.; Iost, A.; Leroy, J.M. The relative influence of the topography and chemistry of TiAl6V4 surfaces on osteoblastic cell behaviour. Biomaterials 2000, 21, 1567-1577. [CrossRef]

38. Sader, M.S.; Balduino, A.; De Almeida Soares, G.; Borojevic, R. Effect of three distinct treatments of titanium surface on osteoblast attachment, proliferation, and differentiation. Clin. Oral Implants Res. 2005, 16, 667-675. [CrossRef] [PubMed]

39. Schwartz, Z.; Lohmann, C.H.; Vocke, A.K.; Sylvia, V.L.; Cochran, D.L.; Dean, D.D.; Boyan, B.D. Osteoblast response to titanium surface roughness and $1 \alpha, 25-(\mathrm{OH})_{2} \mathrm{D}_{3}$ is mediated through the mitogen-activated protein kinase (MAPK) pathway. J. Biomed. Mater. Res. 2001, 56, 417-426. [CrossRef]

40. Olivares-Navarrete, R.; Raz, P.; Zhao, G.; Chen, J.; Wieland, M.; Cochran, D.L.; Chaudhri, R.A.; Ornoy, A.; Boyan, B.D.; Schwartz, Z. Integrin $\alpha 2 \beta 1$ plays a critical role in osteoblast response to micron-scale surface structure and surface energy of titanium substrates. Proc. Natl. Acad. Sci. USA 2008, 105, 15767-15772. [CrossRef] [PubMed]

41. Olivares-Navarrete, R.; Hyzy, S.L.; Haithcock, D.A.; Cundiff, C.A.; Schwartz, Z.; Boyan, B.D. Coordinated regulation of mesenchymal stem cell differentiation on microstructured titanium surfaces by endogenous bone morphogenetic proteins. Bone 2015, 73, 208-216. [CrossRef] [PubMed]

42. Hocking, L.J.; Whitehouse, C.; Helfrich, M.H. Autophagy: A new player in skeletal maintenance? J. Bone Miner. Res. 2012, 27, 1439-1447. [CrossRef] [PubMed]

43. Elmore, S. Apoptosis: A review of programmed cell death. Toxicol. Pathol. 2007, 35, 495-516. [CrossRef] [PubMed]

44. Lettre, G.; Hengartner, M.O. Developmental apoptosis in C. elegans: A complex CEDnario. Nat. Rev. Mol. Cell Biol. 2006, 7, 97-108. [CrossRef] [PubMed]

45. Levine, B.; Mizushima, N.; Virgin, H.W. Autophagy in immunity and inflammation. Nature 2011, 469, 323-335. [CrossRef] [PubMed]

46. Mizushima, N.; Levine, B. Autophagy in mammalian development and differentiation. Nat. Cell Biol. 2010, 12, 823-830. [CrossRef] [PubMed]

47. Cenci, S. Autophagy, a new determinant of plasma cell differentiation and antibody responses. Mol. Immunol. 2014, 62, 289-295. [CrossRef] [PubMed] 
48. Kaluđerović, M.R.; Schreckenbach, J.P.; Graf, H.-L. First titanium dental implants with white surfaces: Preparation and in vitro tests. Dent. Mater. 2014, 30, 759-768. [CrossRef] [PubMed]

49. Graf, H.-L.; Stoeva, S.; Armbruster, F.P.; Neuhaus, J.; Hilbig, H. Effect of bone sialoprotein and collagen coating on cell attachment to TICER and pure titanium implant surfaces. Int. J. Oral Maxillofac. Surg. 2008, 37, 634-640. [CrossRef] [PubMed]

50. Altinci, P.; Can, G.; Gunes, O.; Ozturk, C.; Eren, H. Stability and marginal bone level changes of slactive titanium-zirconium implants placed with flapless surgery: A prospective pilot study. Clin. Implant Dent. Relat. Res. 2016. [CrossRef] [PubMed]

51. Allen, P.F.; Lee, S.; Brady, P. Clinical and subjective evaluation of implants in patients with hypodontia: A two-year observation study. Clin. Oral Implants Res. 2016. [CrossRef] [PubMed]

52. Kalemaj, Z.; Scarano, A.; Valbonetti, L.; Rapone, B.; Grassi, F.R. Bone response to four dental implants with different surface topographies: A histologic and histometric study in minipigs. Int. J. Periodontics Restor. Dent. 2016, 36, 745-754. [CrossRef] [PubMed]

53. Marković, A.; Đinić, A.; Calvo Guirado, J.L.; Tahmaseb, A.; Šćepanović, M.; Janjić, B. Randomized clinical study of the peri-implant healing to hydrophilic and hydrophobic implant surfaces in patients receiving anticoagulants. Clin. Oral Implants Res. 2016. [CrossRef] [PubMed]

54. Favero, V.; Lang, N.P.; Favero, R.; Antunes, A.A.; Salata, L.A.; Botticelli, D. Sequential morphometric evaluation at UnicCa ${ }^{\circledR}$ and SLActive ${ }^{\circledR}$ implant surfaces. An experimental study in the dog. Clin. Oral Implants Res. 2016. [CrossRef] [PubMed]

55. Park, S.-H.; Park, K.-S.; Cho, S.-A. Comparison of removal torques of SLActive ${ }^{\circledR}$ implant and blasted, laser-treated titanium implant in rabbit tibia bone healed with concentrated growth factor application. J. Adv. Prosthodont. 2016, 8, 110-115. [CrossRef] [PubMed]

56. Kopf, B.S.; Ruch, S.; Berner, S.; Spencer, N.D.; Maniura-Weber, K. The role of nanostructures and hydrophilicity in osseointegration: In vitro protein-adsorption and blood-interaction studies. J. Biomed. Mater. Res. A 2015, 103, 2661-2672. [CrossRef] [PubMed]

57. Lotz, E.M.; Olivares-Navarrete, R.; Hyzy, S.L.; Berner, S.; Schwartz, Z.; Boyan, B.D. Comparable responses of osteoblast lineage cells to microstructured hydrophilic titanium-zirconium and microstructured hydrophilic titanium. Clin. Oral Implants Res. 2016, 28, e51-e59. [CrossRef] [PubMed]

58. Aboushelib, M.N.; Osman, E.; Jansen, I.; Everts, V.; Feilzer, A.J. Influence of a nanoporous zirconia implant surface of on cell viability of human osteoblasts. J. Prosthodont. 2013, 22, 190-195. [CrossRef] [PubMed]

59. Vlacic-Zischke, J.; Hamlet, S.M.; Friis, T.; Tonetti, M.S.; Ivanovski, S. The influence of surface microroughness and hydrophilicity of titanium on the up-regulation of TGF $\beta$ /BMP signalling in osteoblasts. Biomaterials 2011, 32, 665-671. [CrossRef] [PubMed]

60. Maksimovic-Ivanic, D.; Mijatovic, S.; Harhaji, L.; Miljkovic, D.; Dabideen, D.; Fan Cheng, K.; Mangano, K.; Malaponte, G.; Al-Abed, Y.; Libra, M.; et al. Anticancer properties of the novel nitric oxide-donating compound (S,R)-3-phenyl-4,5-dihydro-5-isoxazole acetic acid-nitric oxide in vitro and in vivo. Mol. Cancer Ther. 2008, 7, 510-520. [CrossRef] [PubMed]

61. Mojic, M.; Mijatovic, S.; Maksimovic-Ivanic, D.; Miljkovic, D.; Stosic-Grujicic, S.; Stankovic, M.; Mangano, K.; Travali, S.; Donia, M.; Fagone, P.; et al. Therapeutic potential of nitric oxide-modified drugs in colon cancer cells. Mol. Pharmacol. 2012, 82, 700-710. [CrossRef] [PubMed]

62. Yang, T.; Peleli, M.; Zollbrecht, C.; Giulietti, A.; Terrando, N.; Lundberg, J.O.; Weitzberg, E.; Carlström, M. Inorganic nitrite attenuates NADPH oxidase-derived superoxide generation in activated macrophages via a nitric oxide-dependent mechanism. Free Radic. Biol. Med. 2015, 83, 159-166. [CrossRef] [PubMed]

63. Yousfi, N.; Pruvot, B.; Lopez, T.; Magadoux, L.; Franche, N.; Pichon, L.; Salvadori, F.; Solary, E.; Garrido, C.; Laurens, V.; et al. The impact of tumor nitric oxide production on VEGFA expression and tumor growth in a zebrafish rat glioma xenograft model. PLoS ONE 2015, 10, e0120435. [CrossRef] [PubMed]

64. Delic, J.; Coppey, J.; Magdelenat, H.; Coppey-Moisan, M. Impossibility of acridine orange intercalation in nuclear DNA of the living cell. Exp. Cell Res. 1991, 194, 147-153. [CrossRef]

65. Zelenin, A.V. Chapter nine-Acridine Orange as a Probe for Cell and Molecular Biology. In Fluorescent and Luminescent Probes for Biological Activity, 2nd ed.; Mason, W.T., Ed.; Academic Press: London, UK, 1999; pp. 117-135. 
66. Chen, S.-S.; Hu, W.; Wang, Z.; Lou, X.-E.; Zhou, H.-J. p8 attenuates the apoptosis induced by dihydroartemisinin in cancer cells through promoting autophagy. Cancer Biol. Ther. 2015, 16, 770-779. [CrossRef] [PubMed]

67. Li, Y.; Zhang, L.; Zhou, J.; Luo, S.; Huang, R.; Zhao, C.; Diao, A. Nedd4 E3 ubiquitin ligase promotes cell proliferation and autophagy. Cell Prolif. 2015, 48, 338-347. [CrossRef] [PubMed]

68. Wennerberg, A.; Jimbo, R.; Stübinger, S.; Obrecht, M.; Dard, M.; Berner, S. Nanostructures and hydrophilicity influence osseointegration: A biomechanical study in the rabbit tibia. Clin. Oral Implants Res. 2014, 25, 1041-1050. [CrossRef] [PubMed]

69. Medvedev, A.E.; Molotnikov, A.; Lapovok, R.; Zeller, R.; Berner, S.; Habersetzer, P.; Dalla Torre, F. Microstructure and mechanical properties of Ti-15Zr alloy used as dental implant material. J. Mech. Behav. Biomed. Mater. 2016, 62, 384-398. [CrossRef] [PubMed]

70. Jäger, M.; Zilkens, C.; Zanger, K.; Krauspe, R. Significance of nano- and microtopography for cell-surface interactions in orthopaedic implants. J. Biomed. Biotechnol. 2007, 2007, 69036. [CrossRef] [PubMed]

71. Fini, M.; Cigada, A.; Rondelli, G.; Chiesa, R.; Giardino, R.; Giavaresi, G.; Aldini, N.N.; Torricelli, P.; Vicentini, B. In vitro and in vivo behaviour of Ca- and P-enriched anodized titanium. Biomaterials 1999, 20, 1587-1594. [CrossRef]

72. Rouahi, M.; Champion, E.; Gallet, O.; Jada, A.; Anselme, K. Physico-chemical characteristics and protein adsorption potential of hydroxyapatite particles: Influence on in vitro biocompatibility of ceramics after sintering. Colloids Surf. B 2006, 47, 10-19. [CrossRef] [PubMed]

73. De Angelis, E.; Ravanetti, F.; Cacchioli, A.; Corradi, A.; Giordano, C.; Candiani, G.; Chiesa, R.; Gabbi, C.; Borghetti, P. Attachment, proliferation and osteogenic response of osteoblast-like cells cultured on titanium treated by a novel multiphase anodic spark deposition process. J. Biomed. Mater. Res. B Appl. Biomater. 2009, 88, 280-289. [CrossRef] [PubMed]

74. Veis, A.A.; Papadimitriou, S.; Trisi, P.; Tsirlis, A.T.; Parissis, N.A.; Kenealy, J.N. Osseointegration of Osseotite and machined-surfaced titanium implants in membrane-covered critical-sized defects: A histologic and histometric study in dogs. Clin. Oral Implants Res. 2007, 18, 153-160. [CrossRef] [PubMed]

75. Manduca, P.; Palermo, C.; Caruso, C.; Brizzolara, A.; Sanguineti, C.; Filanti, C.; Zicca, A. Rat tibial osteoblasts III: Propagation in vitro is accompanied by enhancement of osteoblast phenotype. Bone 1997, 21, 31-39. [CrossRef]

76. Isaac, J.; Galtayries, A.; Kizuki, T.; Kokubo, T.; Berda, A.; Sautier, J.-M. Bioengineered titanium surfaces affect the gene-expression and phenotypic response of osteoprogenitor cells derived from mouse calvarial bones. Eur. Cells Mater. 2010, 20, 178-196. [CrossRef]

77. Yamamichi, N.; Pugdee, K.; Chang, W.-J.; Lee, S.-Y.; Yoshinari, M.; Hayakawa, T.; Abiko, Y. Gene expression monitoring in osteoblasts on titanium coated with fibronectin-derived peptide. Dent. Mater. J. 2008, 27, 744-750. [CrossRef] [PubMed]

78. Komori, T. Regulation of bone development and extracellular matrix protein genes by RUNX2. Cell Tissue Res. 2010, 339, 189-195. [CrossRef] [PubMed]

79. De Oliveira, P.T.; Nanci, A. Nanotexturing of titanium-based surfaces upregulates expression of bone sialoprotein and osteopontin by cultured osteogenic cells. Biomaterials 2004, 25, 403-413. [CrossRef]

80. Ganss, B.; Kim, R.H.; Sodek, J. Bone sialoprotein. Crit. Rev. Oral Biol. Med. 1999, 10, 79-98. [CrossRef] [PubMed]

81. Le Guéhennec, L.; Soueidan, A.; Layrolle, P.; Amouriq, Y. Surface treatments of titanium dental implants for rapid osseointegration. Dent. Mater. 2007, 23, 844-854. [CrossRef] [PubMed]

82. Lundberg, P.; Boström, I.; Mukohyama, H.; Bjurholm, A.; Smans, K.; Lerner, U.H. Neuro-hormonal control of bone metabolism: Vasoactive intestinal peptide stimulates alkaline phosphatase activity and mRNA expression in mouse calvarial osteoblasts as well as calcium accumulation mineralized bone nodules. Regul. Pept. 1999, 85, 47-58. [CrossRef]

83. Liu, F.; Fang, F.; Yuan, H.; Yang, D.; Chen, Y.; Williams, L.; Goldstein, S.A.; Krebsbach, P.H.; Guan, J.-L. Suppression of autophagy by FIP200 deletion leads to osteopenia in mice through the inhibition of osteoblast terminal differentiation. J. Bone Miner. Res. 2013, 28, 2414-2430. [CrossRef] [PubMed]

84. Pantovic, A.; Krstic, A.; Janjetovic, K.; Kocic, J.; Harhaji-Trajkovic, L.; Bugarski, D.; Trajkovic, V. Coordinated time-dependent modulation of AMPK/Akt/mTOR signaling and autophagy controls osteogenic differentiation of human mesenchymal stem cells. Bone 2013, 52, 524-531. [CrossRef] [PubMed] 
85. Chow, J.W. Role of nitric oxide and prostaglandins in the bone formation response to mechanical loading. Exerc. Sport Sci. Rev. 2000, 28, 185-188. [PubMed]

86. Van't Hof, R.J.; Ralston, S.H. Nitric oxide and bone. Immunology 2001, 103, 255-261. [CrossRef] [PubMed]

87. Saura, M.; Tarin, C.; Zaragoza, C. Recent insights into the implication of nitric oxide in osteoblast differentiation and proliferation during bone development. Sci. World J. 2010, 10, 624-632. [CrossRef] [PubMed]

88. Vatsa, A.; Smit, T.H.; Klein-Nulend, J. Extracellular NO signalling from a mechanically stimulated osteocyte. J. Biomech. 2007, 40 (Suppl. 1), S89-S95. [CrossRef] [PubMed]

89. Dröge, W. Free radicals in the physiological control of cell function. Physiol. Rev. 2002, 82, 47-95. [CrossRef] [PubMed]

90. King, J.S. Mechanical stress meets autophagy: Potential implications for physiology and pathology. Trends Mol. Med. 2012, 18, 583-588. [CrossRef] [PubMed]

91. King, J.S.; Veltman, D.M.; Insall, R.H. The induction of autophagy by mechanical stress. Autophagy 2011, 7, 1490-1499. [CrossRef] [PubMed]

92. Wennerberg, A.; Albrektsson, T. On implant surfaces: A review of current knowledge and opinions. Int. J. Oral Maxillofac. Implants 2010, 25, 63-74. [PubMed]

93. Mujoo, K.; Krumenacker, J.S.; Murad, F. Nitric oxide-cyclic GMP signaling in stem cell differentiation. Free Radic. Biol. Med. 2011, 51, 2150-2157. [CrossRef] [PubMed]

94. Altuna, P.; Lucas-Taulé, E.; Gargallo-Albiol, J.; Figueras-Álvarez, O.; Hernández-Alfaro, F.; Nart, J. Clinical evidence on titanium-zirconium dental implants: A systematic review and meta-analysis. Int. J. Oral Maxillofac. Surg. 2016, 45, 842-850. [CrossRef] [PubMed]

(C) 2017 by the authors. Licensee MDPI, Basel, Switzerland. This article is an open access article distributed under the terms and conditions of the Creative Commons Attribution (CC BY) license (http://creativecommons.org/licenses/by/4.0/). 